\begin{tabular}{|l|l|l}
\hline Received : October 2020 & Accepted: November 2020 & Published : January 2021
\end{tabular}

\title{
Pemanfaatan Google Earth dan Schoology dalam Pembelajaran Jarak Jauh Project Base Learning
}

\author{
Widodo ${ }^{1}$ \\ 1*Program Studi Geologi Pertambangan, SMKN 1 Balikpapan \\ *Email : widodo@smkn1-bpn.sch.id
}

\begin{abstract}
Project-based learning (Project Based Learning) in geological mapping learning by utilizing Google Earth as a learning resource (base map) and schoology as a learning media platform is very effective in improving students' problem-solving skills, making students more active and successful in solving problem that is complex related to geological mapping. The purpose of writing this scientific article is to provide an overview of the use of google earth and schoology in remote project based learning. This scientific article uses a methodology in the form of google earth digital image processing and presentation of results through schoology and literature studies. Based on google earth satellite images, the appearance of geological objects that can be observed and interpreted properly and clearly are used in geological mapping such as lithology/rocks, stratigraphy, geomorphology and geological structures such as fractures, folds and faults. The project based distance learning using schoology platform media makes it easier to present, document, store, monitor and evaluate the results of the geological interpretation of the google earth landscape image more effectively and efficiently.
\end{abstract}

Keywords: google earth, pembelajaran jarak jauh

\begin{abstract}
Abstrak
Pembelajaran berbasis proyek (Project Based Learning) dalam pembelajaran pemetaan geologi dengan memanfaatkan google earth sebagai sumber belajar (peta dasar) dan schoology sebagai platform media pembelajaran sangat efektif digunakan untuk meningkatkan kemampuan memecahkan masalah siswa, membuat siswa lebih aktif dan berhasil memecahkan masalah-masalah yang bersifat kompleks terkait pemetaan geologi. Tujuan dari penulisan artikel ilmiah ini adalah untuk memberikan gambaran pemanfaatan google earth dan schoology dalam pembelajaran berbasis proyek secara jarak jauh. Artikel ini menggambarkan langkah- langkah pembelajaran berupa pengolahan citra satelit google earth dan penyajian hasil melalui schoology serta studi pustaka. Berdasarkan citra satelit google earth, kenampakan obyek-obyek geologi dapat diamati dan diinterpretasi dengan baik dan jelas yang dipakai dalam pemetaan geologi seperti litologi/batuan, stratigrafi, geomorfologi dan struktur geologi seperti kekar, lipatan maupun sesar. Adapun pembelajaran jarak jauh berbasis proyek dengan menggunakan media platform schoology ini memudahkan dalam menyajikan, mendokumentasikan, menyimpan, memonitoring dan mengevaluasi hasil intrepretasi geologi dari citra satelit google earth tersebut secara lebih efektif dan efisien.
\end{abstract}

Kata kunci: google earth, pembelajaran jarak jauh

\section{Pendahuluan}

1.1. Pembelajaran Jarak Jauh Pemetaan Topografi dan Geologi

Proses pembelajaran jarak jauh berbasis proyek/Project Based Learning ini berpotensi besar dilakukan secara virtual/online pada matadiklat pemetaan topografi dan geologi program studi keahlian geologi pertambangan. Penjelasan materi dan praktik langsung menggunakan google earth melalui video conference meeting teams office 365 yang terintegrasi di platform schoology secara virtual/online. Pengumpulan tugas proyek ini langsung melalui schoology yang dapat dimonitoring dan dievaluasi secara real time dan bersama baik oleh siswa maupun guru. 


\subsection{Media Citra Satelit Google Earth Dalam Pemetaan Topografi dan Geologi}

Citra satelit dari google earth yang digunakan yaitu citra satelit daerah Iran dengan kordinat

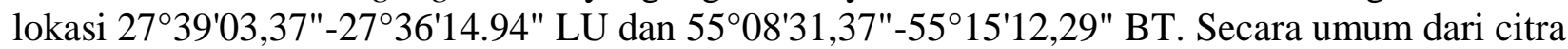
satelit daerah tersebut memperlihatkan bermacam kenampakan obyek geologi yang cukup lengkap mulai dari litologi/batuan, stratigrafi, geomorfologi dan struktur geologi seperti kekar, lipatan maupun sesar. Hasil interpretasi geologi citra satelit dari google earth tersebut disajikan dalam bentuk peta interpretasi yang kemudian dikumpulkan secara online di schoology untuk dikoreksi, diperbaiki dan dievaluasi. Dalam pekerjaan eksplorasi, hasil interpretasi geologi citra satelit ini bisa digunakan sebagai data awal sebelum melakukan eksplorasi secara detail.

\section{Metodologi}

\subsection{Metode}

Metode yang digunakan yaitu menggunakan metode penginderaan jarak jauh (remote sensing) dan studi pustaka. Metode terbagi menjadi 4 tahapan, yaitu tahap pengumpulan data, tahap pengolahan data, tahap analisis data dan tahap penyajian hasil. Penulis menggunakan metode remote sensing yaitu penggunaan data citra satelit dari google earth yang diperoleh dari laman google earth pro. Semua proses pembelajaran berbasis proyek/Project Based Learning ini dilakukan secara virtual/online melalui video conference/pembelajaran jarak jauh menggunakan meeting teams office 365 yang terintegrasi dalam paltform schoology mulai dari penyampaian materi, analisis sampai pengumpulan hasilnya.

\subsection{Tahapan Pembelajaran}

Adapun tahapan pembelajaran ini adalah sebagai berikut :

a. Tahapan pertama yaitu melakukan pengumpulan data secara online yang dibutuhkan yang berasal dari citra satelit google earth daerah Iran dengan kordinat lokasi $27^{\circ} 39^{\prime} 03,37^{\prime \prime}-$

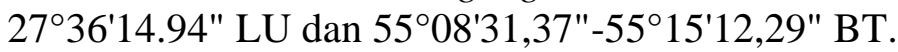

b. Tahapan kedua yaitu melakukan pengolahan data secara online yang diperoleh dari interpretasi kenampakan-kenampakan obyek geologi seperti litologi/batuan, stratigrafi, geomorfologi dan struktur geologi seperti kekar, lipatan maupun sesar yang dijumpai di daerah tersebut.

c. Tahapan ketiga yaitu melakukan analisis data secara online. Analisis data dilakukan secara kualitatif dan kuantitatif. Secara kuantitatif besar nilai rata-rata slope, beda tinggi, sudut kemiringan lapisan dan arah azimut digunakan untuk menentukan gemorfologi dan struktur geologi. Secara kualitatif, indikator perbedaan warna, pola garis-garis tertentu, tinggi-rendah daerah, kemenerusan pola perlapisan secara umum, pola aliran digunakan untuk menentukan jenis batuan, batas-batas sebaran batuan, hubungan antar batuan, jenis-jenis bentang alam, batasbatas perbedaan bentang alam, jenis sesar, keterdapatan kekar, jenis lipatan dan sumbu lipatan. Untuk menganalisis lebih detail kenampakan-kenampakan obyek geologi, citra satelit google earth daerah tersebut dilakukan zoom in dan zoom out serta diproyeksikan secara 3D.

d. Tahapan keempat yaitu penyajian hasil berupa peta interpretasi geomorfologi dan geologi yang dikumpulkan secara online melalui platform schoology.

\section{Hasil dan Pembahasan}

\subsection{Interpretasi Data Citra Satelit Google Earth}

Kenampakan obyek-obyek geologi yang bisa diinterpretasikan dari citra satelit google earth

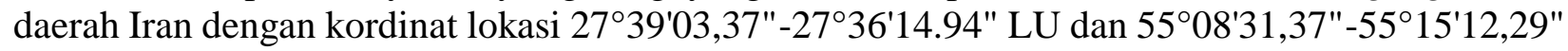
BT dalam matadiklat pemetaan topografi dan geologi ini adalah sebagai berikut. 


\section{a. Geomorfologi}

Interpretasi geomorfologi dilakukan dengan menganalisis besar rata-rata slope dan beda tinggi daerah tesebut di citra satelit google earth dengan cara membuat beberapa profil topografi (Gambar 1). Secara geomorfologi dengan menggunakan klasifikasi Van Zuidam (1985), daerah tersebut dapat dibedakan menjadi satuan bergelombang miring kipas koluvial memiliki slope $7,8 \%$, beda tinggi 104,7 m dan tersusun oleh endapan koluvial. Satuan perbukitan curam intrusi memiliki slope 46,23\%, beda tinggi $289 \mathrm{~m}$ dan dikontrol oleh intrusi batuan beku. Satuan perbukitan curam struktural memiliki slope 47,46\%, beda tinggi 474,6 $\mathrm{m}$ dan dikontrol oleh sesar dan antiklin (Gambar 2).
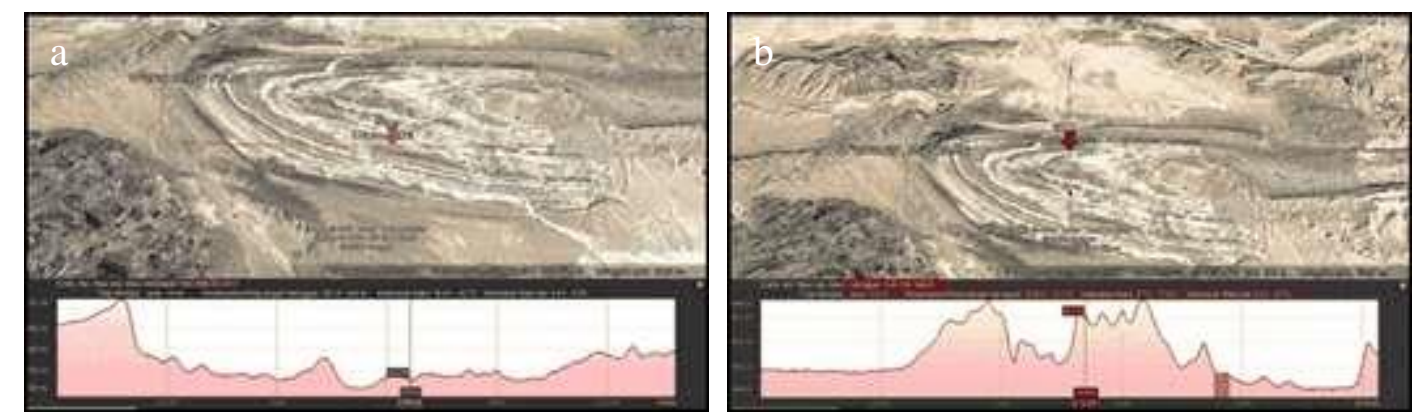

Gambar 1. Profil Geomorfologi dari Google Earth. Profil T-B (a) dan U-S (b)
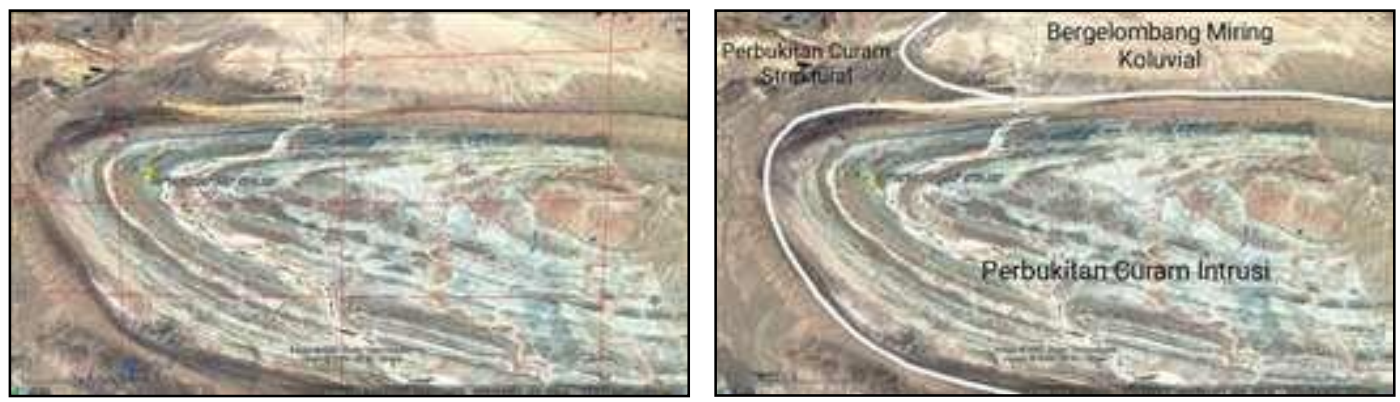

Gambar 2. Interpretasi Geomorfologi dari Google Earth

b. Stratigrafi

Untuk membedakan jenis-jenis batuan dan hubungan antar jenis batuan di daerah tersebut secara umum dilakukan dengan menginterpretasikan perbedaan resistensi batuan yang dicerminkan dengan perbedan morfologi, warna batuan, kesan dijumpainya lapisan dan pola aliran tertentu. Hasil intrepretasi citra satelit google earth daerah tersebut dijumpai endapan, batuan sedimen, batuan beku dan batuan ubahan/batuan teralterasi.

Adapun pembagian satuan batuan dari tua ke muda hasil interpretasi tersebut yaitu satuan batuan sedimen A, satuan batuan sedimen B, intrusi batuan beku dan endapan kipas koluvial (Gambar 3). Satuan batuan sedimen A dicirikan dengan warna coklat dan kebiruan yang menunjukkan batuan ini teralterasi akibat terobosan intrusi batuan beku, berlapis dengan strike/dip dari google earth $\mathrm{N} 110^{\circ} \mathrm{E} / 30^{\circ} \mathrm{N}, \mathrm{N} 260^{\circ} \mathrm{E} / 30^{\circ}$ dan $\mathrm{N} 160^{\circ} \mathrm{E} / 30^{\circ}$ dengan ketebalan $10.870 \mathrm{~m}$. Satuan batuan sedimen B dicirikan dengan warna coklat muda-coklat tua, berlapis dengan strike/dip diukur dari google earth $\mathrm{N} 110^{\circ} \mathrm{E} / 15^{\circ}$, dengan ketebalan $1.918 \mathrm{~m}$ selaras di atas satuan batuan sedimen $\mathrm{A}$. Intrusi batuan beku dicirikan dengan warna coklat muda beberapa kebiruan teralterasi, pola aliran mengitari tubuh intrusi, bentuk stock lebar tersingkap 
$>2 \mathrm{~km}$ menerobos satuan batuan sedimen A dan B. Satuan endapan kipas koluvial dicirikan dengan warna yang cerah terlihat kesan butiran lepas, tidak ada perlapisan dan terletak di kaki bukit dengan bentuk endapan seperti kipas ketebalan $>2 \mathrm{~m}$ terletak tidak selaras diatas satuan batuan sedimen B.
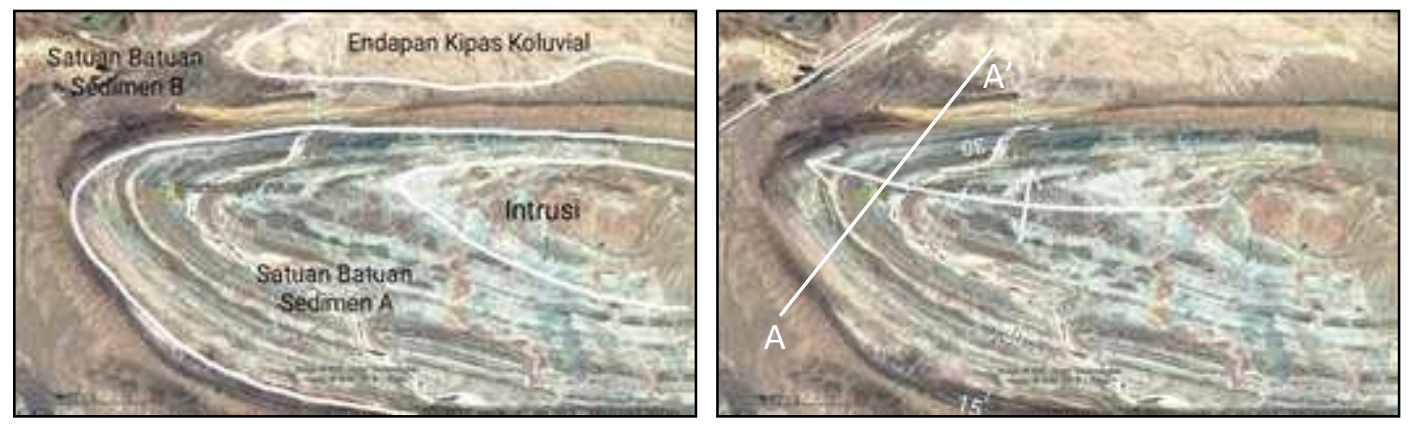

Gambar 3. Interpretasi Stratigrafi dan Struktur Geologi dari Google Earth

\section{c. Struktur Geologi}

Interpretasi struktur geologi di citra satelit google earth dilakukan dengan menganalisis kenampakan kemenerusan perlpisan batuan, bentuk morfologi seperti triangular facet, perbedaan arah dan kemiringan batuan secara mencolok, pola kelurusan atau berbeloknya sungai secara tiba-tiba dan pola kelurusan-pola kelurusan dipermukaan batuan.

Hasil interpretasi struktur geologi (Gambar 3 dan 6) daerah tersebut dijumpai adanya antiklin menunjam yang ditandai dengan arah dip batuan yang berlawanan utara dan selatan dan menutup ke barat. Strike/dip batuan yang dapat diukur dari google earth yaitu $\mathrm{N} 110^{\circ} \mathrm{E} / 30^{\circ}, \mathrm{N}$ $110^{\circ} \mathrm{E} / 15^{\circ}, \mathrm{N} 260^{\circ} \mathrm{E} / 30^{\circ}$ dan N $160^{\circ} \mathrm{E} / 30^{\circ}$ (Gambar 4 dan 5). Sesar geser kiri diukur dari google earth berarah $\mathrm{N} 60^{\circ} \mathrm{E}$ dijumpai di barat laut dengan dicirikan strike/dip batuan berarah $\mathrm{N} 115^{0}$ $\mathrm{E} / 50^{\circ}$ yang berbeda mencolok tiba-tiba dengan batuan sekitarnya, dijumpai drag fold, lapisan batuan yang tiba-tiba tidak menerus/terputus dan pola kelurusan sungai berarah timur laut-barat daya (Gambar 5).
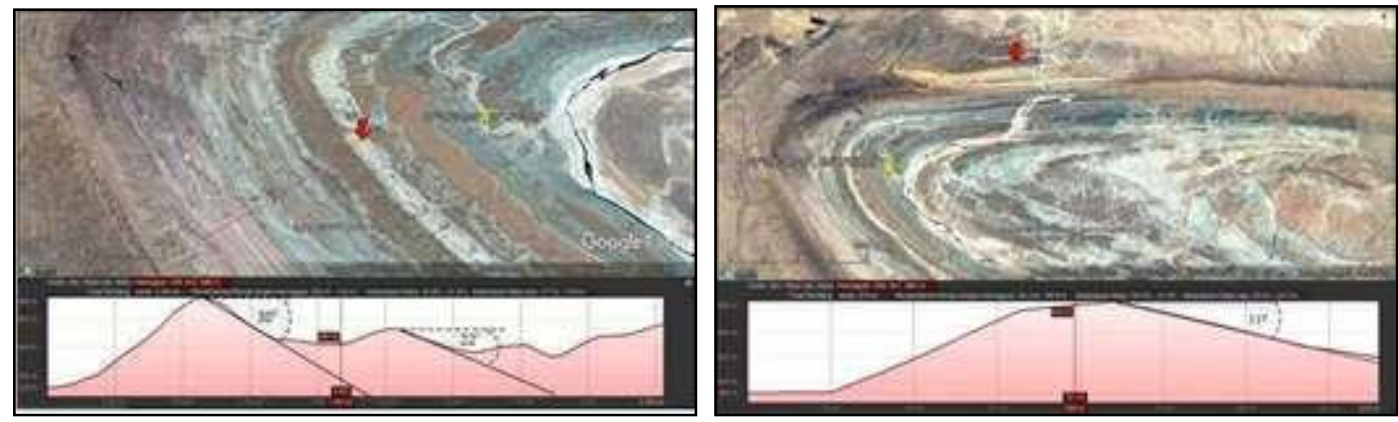

Gambar 4. Profil Penentuan Dip Lapisan Batuan dari Google Earth 

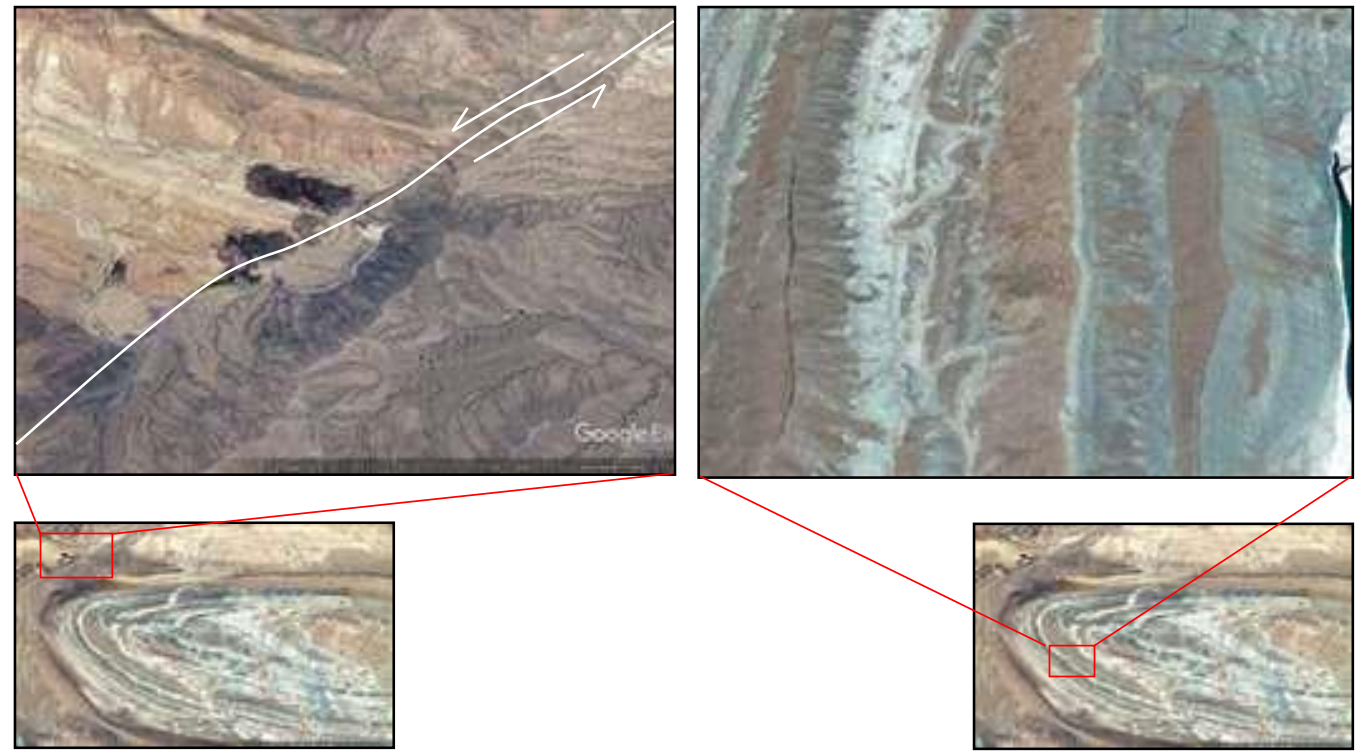

Gambar 5. Interpretasi Sesar Geser Kiri dan Arah Dip dari Google Earth

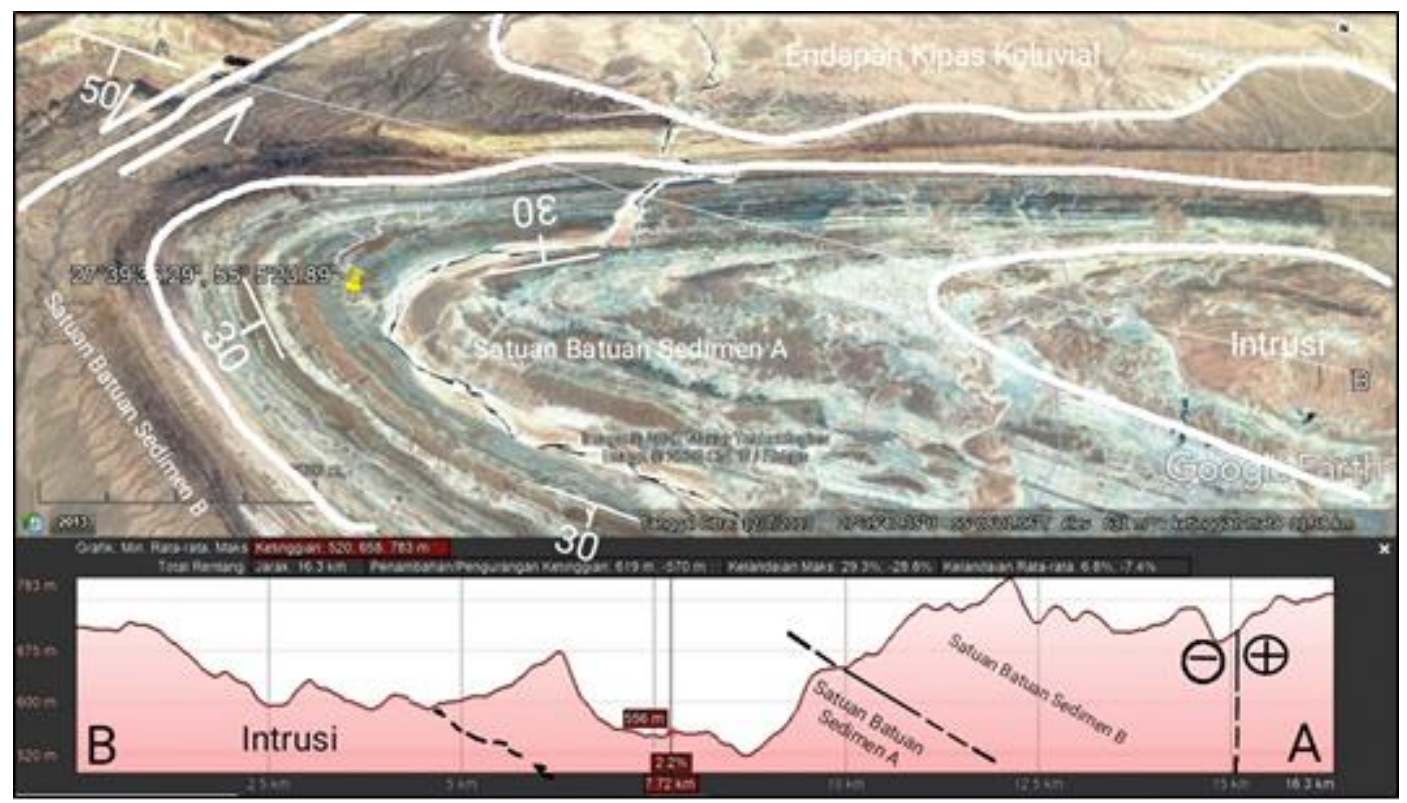

Gambar 6. Penampang Geologi dari Google Earth

\subsection{Dokumentasi dan Penyajian di Platform Schoology}

Hasil interpretasi kenampakan geologi yang telah dianalisis dari citra satelit google earth yang meliputi geomorfologi, stratigrafi dan struktur geologi tersebut kemudian didokumentasikan dan disajikan ke dalam platform pembelajaran jarak jauh schoology untuk didiskusikan, dikoreksi dan dinilai secara langsung (Gambar 7). Feed back hasil koreksi akan dikirim kembali dan 
selanjutnya diperbaiki dan dikirim kembali ke schoology (Gambar 8 dan 9). Apabila hasil sudah memenuhi standar kompetensi selanjutnya penilaian hasil pembelajaran berbasis proyek ini secara langsung disampaikan di schoology (Gambar 10).

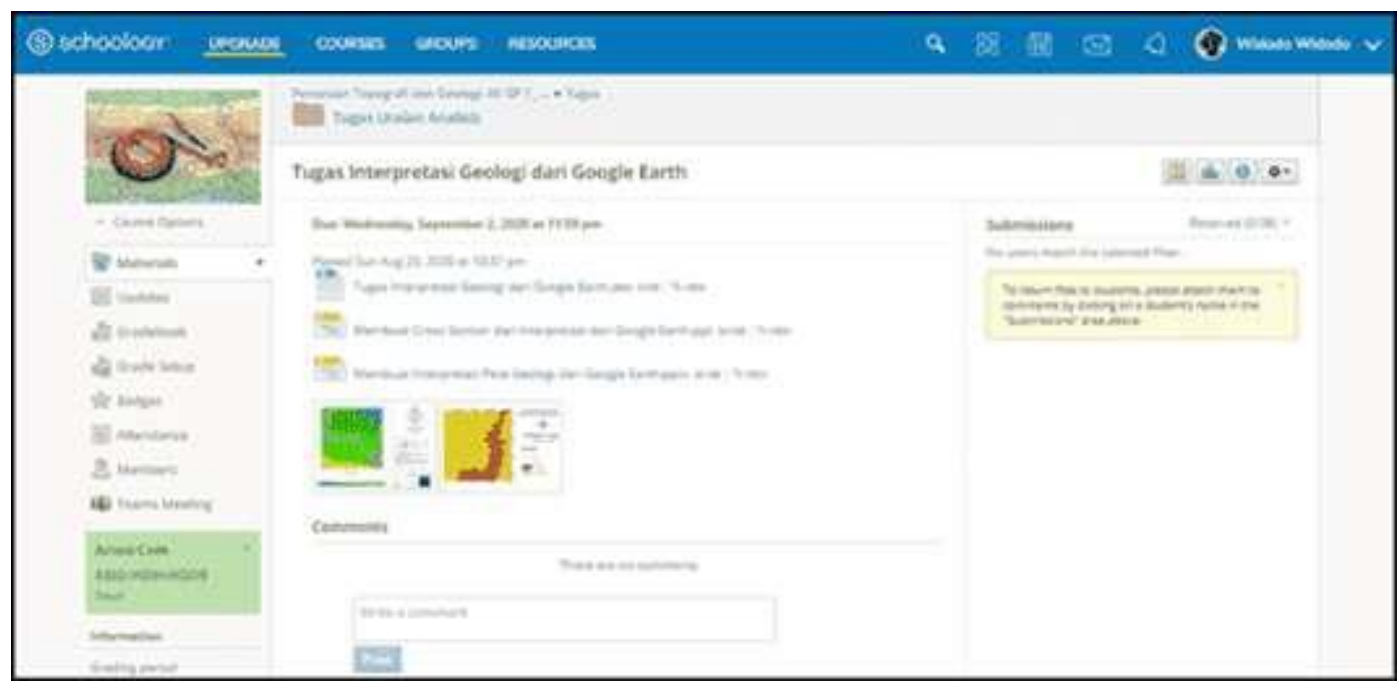

Gambar 7. Platform Schoology Sebagai Media Dokumentasi, Penyajian dan Penilaian

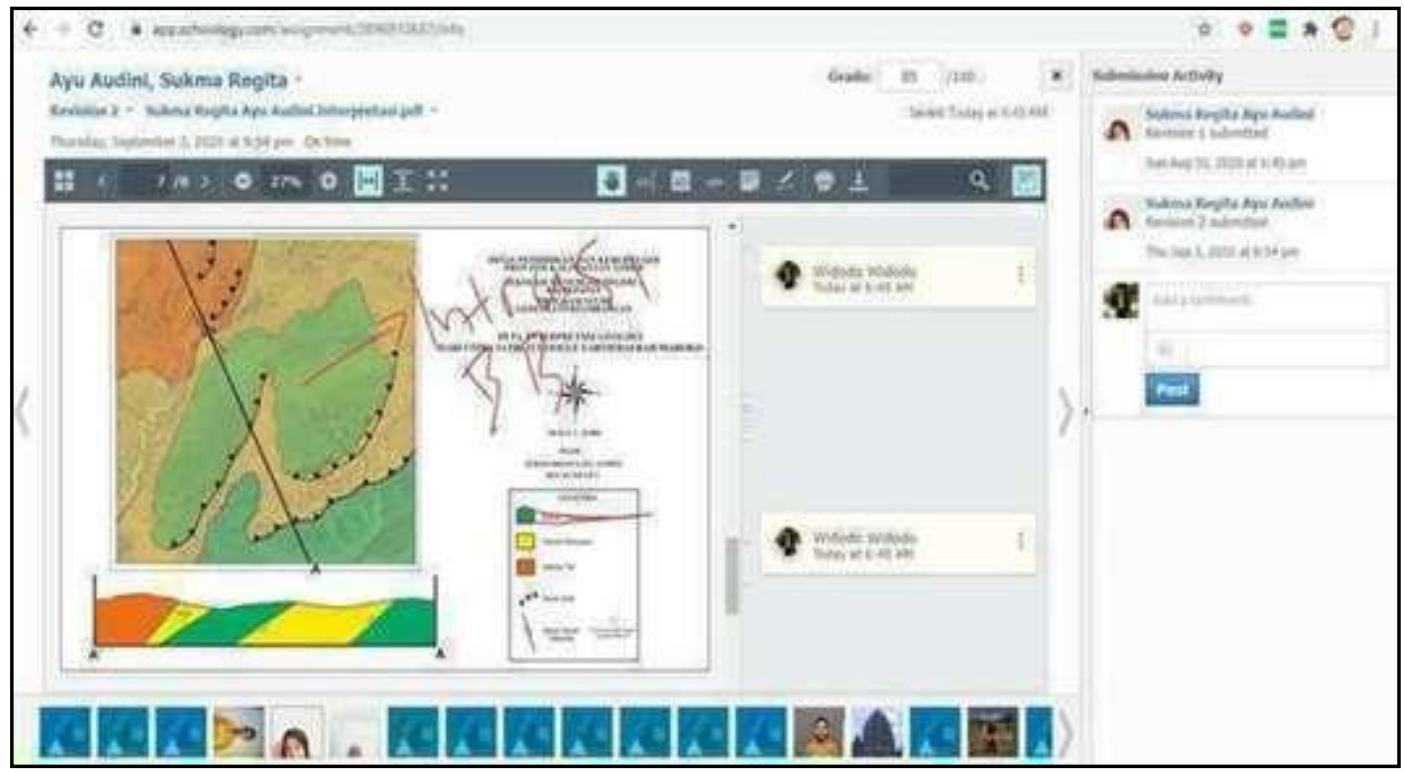

Gambar 8. Pemeriksaan dan Feed Back Hasil Penyelesaian Project Based Learning di Schoology 


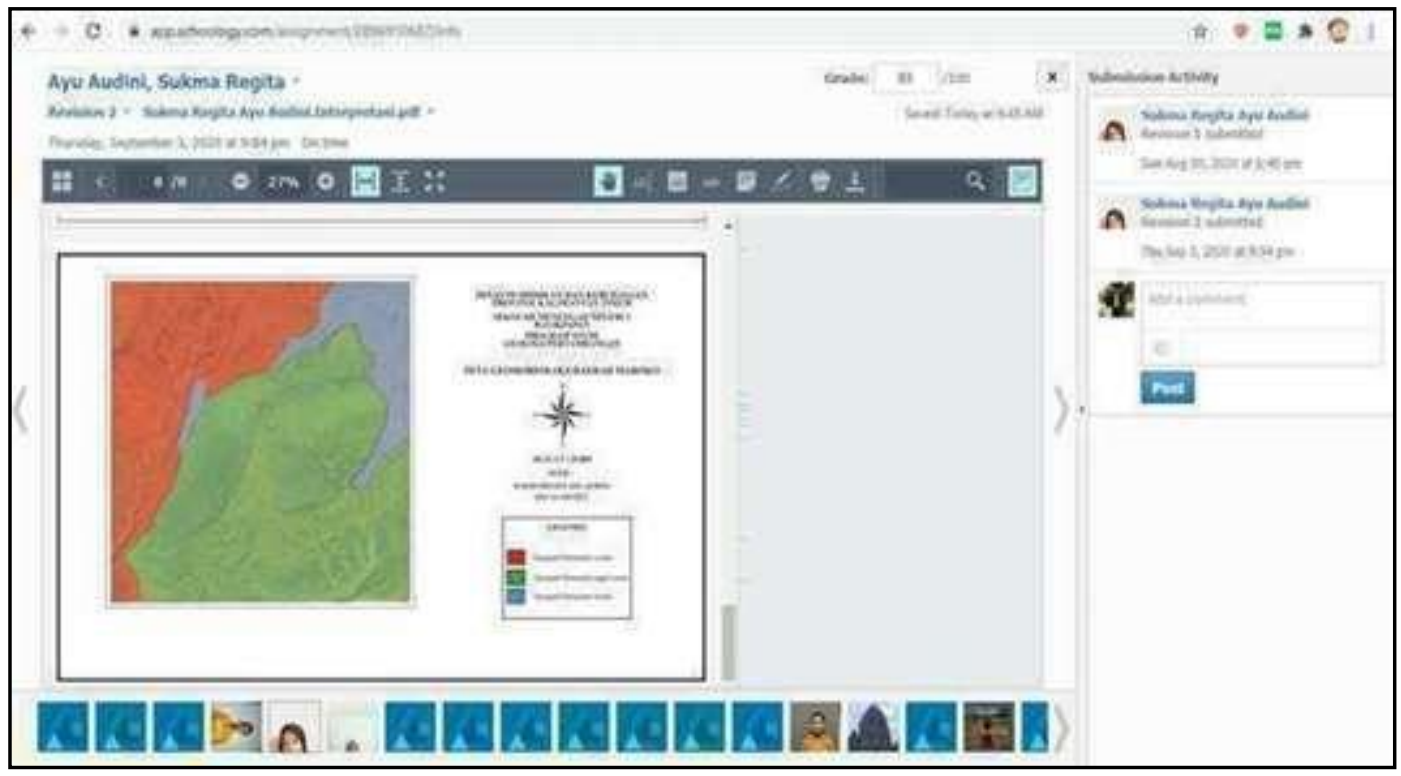

Gambar 9. Pemeriksaan dan Feed Back Hasil Penyelesaian Project Based Learning di Schoology

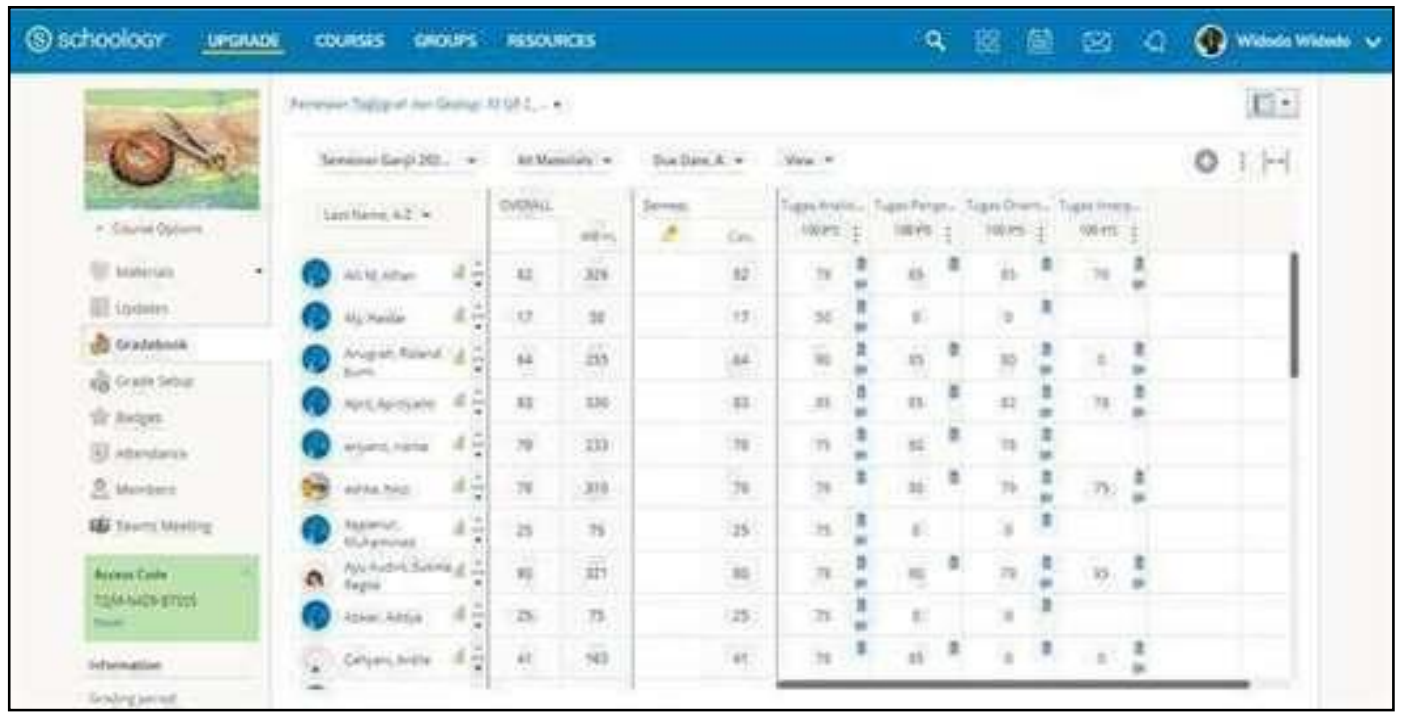

Gambar 10. Penilaian Akhir Hasil Penyelesaian Project Based Learning di Schoology

\section{Kesimpulan}

Pemanfaatan citra satelit google earth sangat diperlukan dan membantu dalam pembelajaran matadiklat pemetaan topografi dan geologi karena data-data geologi seperti geomorfologi, stratigrafi dan struktur geologi dapat dikenal lebih jelas dan area pengamatan bisa lebih luas dan menyeluruh. Hasil interpretasi geomorfologi didapatkan bahwa daerah Iran dengan

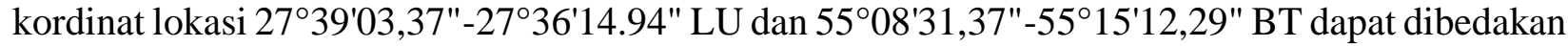
menjadi satuan bergelombang miring kipas koluvial, satuan perbukitan curam intrusi dan satuan perbukitan curam struktural. Stratigrafi daerah tersebut terdiri dari satuan batuan sedimen A, satuan 
batuan sedimen B, intrusi batuan beku dan endapan kipas koluvial. Struktur geologi hasil interpretasi dijumpai adanya sesar geser kiri dan antiklin menunjam.

Platform schoology yang digunakan sebagai media dalam pembelajaran jarak jauh berbasis proyek/Project Based Learning ini sangat membantu memudahkan dalam pengumpulan tugas dan pemeriksaan serta evaluasi penilaian karena secara real time dilakukan sehingga efisien dan efektif karena dapat meminimalisir penggunaan kertas serta komunikasi selama pemelajaran berlangsung tidak dibatasi oleh batas-batas geografis (ruang) dan waktu.

\section{Saran}

Diperlukan penelitian eksperimen di kelas pembelajaran untuk menguji efektifitas pembelajaran mennguanakan Platform schoology yang digunakan sebagai media dalam pembelajaran jarak jauh berbasis proyek/Project Based Learning. Selain itu, diperlukan pengembangan lebih jauh dalam memanfaatkan citra satelit google earth dalam pembelajaran khususnya di program studi keahlian geologi pertambangan sehingga dapat mempermudah siswa dalam memahami obyek-obyek geologi lebih luas dan lebih detail walau tidak secara langsung mengamati di lapangan. Pemanfaatan lebih jauh peggunaan platform pembelajaran seperti schoology, google class, ms teams dan lain sebagainya perlu dilakukan dalam pembelajaran jarak jauh karena dapat mempermudah dalam memonitoring dan mengevaluasi tugas-tugas dalam proses pembelajaran dan dapat mengefiseinsikan sumber daya baik waktu maupun yang lainya.

\section{Ucapan Terimakasih}

Terimakasih kami sampaikan kepada SMK N 1 Balikpapan khususnya program keahlian geologi pertambangan atas segala dukungan yang diberikan sehingga penulisan karya ilmiah ini bisa terlaksana dan terselesaikan dengan baik.

\section{Daftar Pustaka}

Anwar S., Google Earth Sebagai Solusi Pembelajaran Jarak Jauh. URL.https://guruberbagi.kemdikbud.go.id/artikel/google-earth-sebagai-solusipembelajaran-jarak-jauh/

Anymous. (25 Juli 2020). Pembelajaran Berbasis Proyek. URL https://www.dosenpendidikan.co.id/pembelajaran-berbasis-proyek/

Azhar Arsyad, (2004). Media Pembelajaran. Jakarta: Rajawali Press

Dewi A., Andri P, (2014). Pemanfaatan Aplikasi Google Earth Sebagai Media Pembelajaran Geografi Menggunakan Metode Image Enhancement. Simposium Nasional RAPI XIII FT $U M S, \mathrm{E}-165-170$

Gatty A, (2014). Pemanfaatan Google Earth Dalam Pembelajaran Geografi Untuk Meningkatkan Hasil Belajar Siswa Kelas X SMA Widya Kutuarjo. Skripsi, Fakultas Ilmu Sosial Universitas Negeri Yogyakarta

Kadek BI, A. Gede, Luh Putu P, RARE (2015). Pengembangan E-Learning dengan Schoology Pada Mata Pelajaran Bahasa Indonesia Untuk Siswa Kelas X Semester 1 Tahun Pelajaran 2014/2015 di SMAN 4 Singaraja. e-Jurnal Edutech Universitas Pendidikan Ganesa, 124132

N. Rana, Chakravarthy, R. Nair, RARE (2016). Identification of Linements Using Google Tools. Atlantis Press, 124-132

Steven J., John E., Declan G, (2012). Google Earth and Virtual Visualizations in Geoscience Education and Research. Geological Society of America Vol. 492

Wena, M. (2011). Strategi Pembelajaran Inovatif Kontemporer. Jakarta : Bumi Aksara 